\title{
MANAJEMEN DAN KEPEMIMPINAN MADRASAH
}

\author{
Muh. Akib D. \\ Madrasah Aliyah Negeri 1 Soreang Kota Parepare \\ Jl. Amal Bakti Kota Parepare \\ Email: muh.akibd@gmail.com
}

\begin{abstract}
Abstrak:
Aktivitas manajemen mencakup spektrum luas, dimulai dari menentukan arah organisasi, menciptakan kegiatan organisasi, mendorong terbinanya kerjasama, serta mengawasi kegiatan. Manajemen memiliki peranan strategis, terutama untuk membantu pencapaian tujuan dalam mendayagunakan peralatan, lahan, kantor, produk, pelayanan, dan hubungan manusia dalam organisasi. Kepemimpinan pendidikan di madrasah dilandasi konsep demokratisasi, spesialisasi tugas, pendelegasian wewenang, profesionalitas, dan integrasi tugas. Kepemimpinan yang berlangsung pada lembaga pendidikan berarti menjalankan proses kepemimpinan yang sifatnya mempengaruhi sumber daya personel pendidikan. Manajemen madrasah dan pelaksanaan kepemimpinan di madrasah diharapkan mampu mensinkronkan berbagai input atau mensinergikan semua komponen dalam proses pembelajaran, baik antara guru, siswa dan sarana pendukung di kelas dan di luar kelas.
\end{abstract}

\begin{abstract}
:
Management activities covering a broad spectrum, starting from determining organization direction, creating organization activities, encouraging cooperation establishment, as well as supervizing the activities. Management has strategic roles, especially to help the organization meet the goals in utilizing equipment, land, office, product, service, and human relations. Educational leadership at the school level is based on the democratization concept, tasks specialization, authority delegation, professionalism, and tasks integration. Leadership that takes place in educational institutions means running leadership processes that are affecting personnel resources of education. Management and implementation of leadership in Islamic schools (madrassa) are expected to synchronize the various inputs or synergize all components in the learning process among teachers, students and support facilities both inside and outside the classrooms.
\end{abstract}

Kata kunci:

Manajemen, madrasah, dan kepemimpinan

SECARA historis pertumbuhan dan perkembangan pendidikan Islam di Indonesia hampir sama dengan usia kedatangan Islam ke Nusantara. Dalam proses sosialisasi Islam melalui proses pendidikan tersebut, selain dilakukan oleh masyarakat sendiri, juga didukung oleh pemerintah. ${ }^{1}$

Berbagai upaya untuk meningkatkan kualitas penyelenggaraan pendidikan Islam telah dilakukan. Dalam konteks madrasah, telah diterbitkan Surat Keputusan Bersama (SKB) yaitu Menteri Dalam Negeri, Menteri Pendidikan dan Kebudayaan serta Menteri Agama Republik Indonesia pada tahun 1975, Undang-Undang Nomor 2 tahun 1989 tentang Sistem Pendidikan Islam yang kemudian disempurnakan oleh 
Undang-Undang Nomor 20 tahun 2003 beserta berbagai Peraturan Pemerintah yang menyertainya. Namun demikian, hal itu belum cukup untuk memacu kualitas penyelenggaraan pendidikan Islam. Ada banyak faktor yang menyebabkan kondisi ini terjadi baik yang eksternal maupun internal.

Kelahiran madrasah itu sendiri dilatarbelakangi oleh keinginan untuk memberlakukan secara berimbang antara ilmu agama dan ilmu pengetahuan umum dalam kegiatan pendidikan di kalangan umat Islam. ${ }^{2}$ Madrasah sebagai salah satu lembaga pendidikan yang bertujuan untuk menghimpun ilmu pengetahuan umum dan ilmu pengetahuan agama Islam. Di madrasah siswa diharapkan memadukan ketinggian ilmu pengetahuan dan teknologi serta kedalaman iman dan takwa. Madrasah diharapkan menjadi benteng kokoh dan mampu melakukan terobosan-terobosan baru dalam menghadapi tantangan dan modernisasi berkat kemajuan ilmu pengetahuan dan teknologi. ${ }^{3}$

Tantangan yang dihadapi oleh madrasah cukup berat, di antaranya adalah terjadinya perubahan orientasi masyarakat dalam hal pendidikan. Persiapan menuju era industrialisasi telah menyebabkan orientasi pendidikan masyarakat berubah dari "belajar mencari ilmu" menjadi "belajar sebagai persiapan untuk memperoleh pekerjaan". Perubahan orientasi ini membuat sekolah umum lebih menarik minat orangtua daripada madrasah atau pesantren yang menurut anggapan mereka tidak memberikan kontribusi sebagaimana yang mereka harapkan.

Anwar Arifin mengakui bahwa mutu pendidikan di Indonesia sangat terpuruk sehingga memengaruhi kualitas sumber daya manusia (SDM) sebagai modal pembangunan bangsa di masa datang, dan kalah bersaing dengan negara tetangga seperti Malaysia dan Singapura. Terpuruknya mutu sumber daya manusia Indonesia di posisi 112 dari 175 negara tak terlepas dari sangat minimnya dana yang dialokasikan untuk peningkatan kualitas pendidikan. ${ }^{4}$

Hal ini sungguh sangat ironis, karena sebelumnya Malaysia meminta bantuan guru dari Indonesia untuk mengajar di sekolah-sekolah dan universitas di Malaysia. Namun demikian, sekarang justru banyak mahasiswa Indonesia yang melanjutkan studinya ke universitas-universitas di Malaysia. Hal ini tidak terlepas dari minimnya dana yang dialokasikan. Pendapatan Indonesia memang sangat kurang dan lebih banyak tergantung pada bantuan atau pinjaman luar negeri. Padahal Indonesia adalah negara yang makmur, memiliki sumber daya alam yang luar biasa, tetapi tidak dikelola dengan baik dan profesional. Sumber daya alam Indonesia lebih banyak dikelola oleh orang asing dan perusahaan luar negeri, sehingga pendapatan yang berlimpah tersebut lebih banyak dinikmati oleh mereka. Kasus ini terjadi misalnya pada Exxon Mobil di Nangroe Aceh Darussalam atau Freefort di Papua.

Ada beberapa masalah atau hambatan yang dihadapi dalam upaya peningkatan kualitas pendidikan di Indonesia, selain masalah paradigma pendidikan, yang berkaitan dengan penyelenggaraan pendidikan, di antaranya adalah rendahnya kualitas sarana dan prasarana yang dimiliki oleh madrasah, rendahnya kualitas pendidikan dan kesejahteraan guru, rendahnya prestasi siswa, kurangnya pemerataan kesempat- 
an pendidikan, rendahnya relevansi pendidikan dengan kebutuhan, serta mahalnya biaya pendidikan terutama bagi sekolah unggulan.

Perbincangan tentang madrasah telah dilakukan di berbagai tempat dan kesempatan berbeda-beda, tidak terkecuali menyangkut aspek manajemennya. Pengamatan serta analisis tajam telah banyak dihasilkan. Begitu pula pikiran-pikiran cerdas untuk membangun konsep dan rancangan pengembangan madrasah sudah banyak dipublikasikan. Madrasah diyakini menjadi lembaga pendidikan yang mampu mengantarkan peserta didik pada ranah yang lebih komprehensif, meliputi aspek-aspek intelektual, moral, spiritual, dan keterampilan secara terpadu. Madrasah diyakini mampu mengintegrasikan kematangan religius dan keahlian ilmu modern kepada peserta didik sekaligus. Itulah yang sesungguhnya menjadikan orang-orang yang memahami dunia madrasah menjadi begitu gigih memperjuangkan eksistensi madrasah.

Selain itu, para peminat lembaga pendidikan madrasah juga didorong oleh nilai-nilai idealisme. Semestinya madrasah mampu menampilkan diri sebagai representasi ajaran Islam yang agung, indah, dan sempurna. Akan tetapi, pada kenyataannya, madrasah masih sangat jauh dari idealisme itu. Konsep-konsep ideal Islam, seperti suasana kebersamaan, kerja keras, disiplin, optimisme yang menjauhkan dari sifat putus asa, mudah menyerah, selalu menjaga kebersihan baik lahir maupun batin, ternyata belum terwujud dalam aktivitas madrasah. Sebagian besar madrasah masih diliputi oleh suasana dan semangat tradisional, seperti manajemen seadanya, kurang disiplin, bahkan juga tampak kurang bersih, menerima apa adanya dan seterusnya. Akibatnya, madrasah tidak menghasilkan citra dan out-put sebagaimana yang diharapkan sebagai representasi atau personifikasi ajaran Islam itu.

Program pengembangan pendidikan di Indonesia jika masih saja mengabaikan madrasah tentu tidak realistis. Sebab, ternyata jumlah madrasah di tanah air ini cukup banyak, yakni tidak kurang 15\% dari total lembaga pendidikan yang ada. Artinya, jika madrasah tidak di-manage dengan strategi, sistem, dan metodologi yang sama dengan manajemen lembaga pendidikan umum lainnya, maka hal itu berarti mengabaikan sejumlah $15 \%$ dari anak bangsa ini. Jumlah itu bukan merupakan angka yang kecil, apalagi angka itu terkait dengan persoalan pendidikan. ${ }^{5}$

Bagi orang yang mengerti kaitan ihwal pendidikan dengan kehidupan bangsa di masa depan, sudah pasti tidak akan berani membuat keputusan semena-mena dalam menangani pendidikan. Sebab, mengurus pendidikan sesungguhnya sama artinya dengan menyiapkan generasi masa depan. Manajemen pendidikan berarti manajemen generasi muda bangsa. Saat ini, bangsa Indonesia mengalami krisis multi dimensi, banyak pejabat yang korup, membanjirnya jumlah pengangguran, dan kualitas sumber daya manusia yang rendah. Semuanya itu merupakan produk dari penyelenggaraan pendidikan yang timpang, salah satunya madrasah kurang memperoleh perhatian yang memadai. Sekian lama madrasah terkesan dianaktirikan oleh pemerintah, baik secara institusional maupun finansial.

Secara hakiki bangsa Indonesia yang sedang terpuruk ini hanya dapat diselesaikan lewat perbaikan-perbaikan dalam bidang pengembangan pendidikan. Memban- 
gun pendidikan secara layak, tak terkecuali mengangkat harkat martabat madrasah melalui upaya-upaya memperkokoh berbagai aspeknya.

Meskipun secara umum nasib madrasah memprihatinkan, namun tidak semua madrasah kondisi dan prestasinya kurang baik. Ada madrasah yang performa dan prestasinya jauh lebih unggul di banding sekolah umum pada umumnya. Hanya saja, jumlah madrasah yang tergolong maju seperti itu masih sangat sedikit sehingga menimbulkan kesan stigmatik. Di Malang, Jawa Timur terdapat madrasah yang justru menjadi rebutan banyak orang, sementara sekolah umum lainnya kekurangan peminat. Madrasah unggul itu, antara lain Madrasah Terpadu (MIN Malang I, MTsN, dan MAN III), Madrasah Sabilillah dan Madrasah Ibtidaiyah Jenderal Sudirman. Dua yang disebutkan terakhir berstatus swasta. Orang tua yang menyekolahkan ke lembaga pendidikan Islam ini pada umumnya secara ekonomi berasal dari keluarga kelas menengah ke atas. Pada umumnya, mereka adalah para dosen, pengusaha, pejabat pemerintah, pedagang, dan kalangan profesional sejenisnya. Madrasah Terpadu, memang memperoleh pendanaan dari pemerintah; namun, karena jumlahnya terbatas, maka madrasah berusaha menghimpun dana partisipasi masyarakat yang cukup besar, baik berupa uang pangkal maupun SPP setiap bulan. Begitu pula dua madrasah lainnya yang berstatus swasta. Madrasah-madrasah seperti ini mampu merekrut tenaga guru secara selektif dan menggajinya secara layak, juga memenuhi sarana dan prasarana pendidikan yang dibutuhkan serta kebutuhan lainnya. Oleh karena ditunjang oleh manajemen dan kepemimpinan yang baik, sarana dan prasarana yang cukup, guru yang berkualitas serta lingkungan yang baik, maka madrasah ini mampu bersaing dengan sekolah-sekolah unggul lainnya di kota ini. Pengelola madrasah yang memiliki kemampuan manajerial dan ditunjang oleh komitmen dan integritas tinggi dan ditunjang oleh kekuatan masyarakat terutama dari ekonomi, rupanya menjadi kunci kemajuan lembaga pendidikan Islam, baik pada tingkat ibtidaiyah hingga perguruan tinggi.

Selain terdapat madrasah yang tergolong maju sebagaimana diungkapkan di atas, di manamana terutama di wilayah pedesaan terdapat banyak madrasah yang kondisinya amat memprihatinkan. Pada umumnya madrasah yang kurang maju berada di lingkungan masyarakat yang secara ekonomi lemah kendatipun perhatian mereka kepada madrasah cukup tinggi. Madrasah itu dikelola oleh yayasan-yayasan sosial-keagamaan (Islam), yang umumnya tidak memiliki sumber dana dan juga manajerial serta leadership yang kokoh. Akibatnya, madrasah yang dikelola berjalan secara linear apa adanya. Para guru, selain diperoleh dari bantuan pemerintah yang pada umumnya jumlahnya kurang mencukupi, juga ditambah dengan guru honorer dengan gaji yang amat kecil. Sumber pendanaan yang kecil itu, pada umumnya diperoleh dari partisipasi masyarakat wali murid, baik berupa sumbangan uang pangkal atau SPP yang harus dibayar setiap bulan. Besarnya sumbangan biaya pendidikan ini, karena masyarakatnya secara ekonomi lemah, maka amat terbatas.

Membaca fenomena madrasah sebagaimana dikemukakan di atas, maka upaya menumbuhkembangkannya harus dibedakan antara madrasah yang sudah kuat hi- 
dup atau survival sebagaimana contoh madrasah unggulan dan mereka yang masih perlu dibantu kehidupannya sebagaimana yang banyak terdapat di pedesaan. Bagi madrasah yang sudah survival maka yang diperlukan adalah peningkatan kemampuan manajerial dan leadership madrasah, peningkatan kemampuan guru baik menyangkut penguasaan metodologi maupun materi bidang keilmuan, administrasi madrasah dan sejenisnya. Akan tetapi, bagi madrasah yang masih berjuang untuk hidup yang jumlahnya amat besar, yang diperlukan dan cukup mendesak bagi mereka adalah bagaimana agar kebutuhan hidup minimal para guru terpenuhi. Jika hal ini saja tidak dapat dipenuhi maka sulit diharapkan madrasah mampu mengembangkan diri, apalagi peningkatan mutu hasil pendidikannya.

Berdasarkan latar belakang masalah tersebut, maka masalah pokok dalam tulisan ini adalah bagaimana manajemen dan kepemimpinan madrasah. Dari masalah pokok, dapat dijadikan sub pokok sebagai berikut:

1. Bagaimana tinjauan dan fungsi manajemen?

2. Bagaimana kepemimpinan kependidikan di madrasah?

3. Bagaimana konsep manajemen dan kepemimpinan madrasah?

\section{PEMBAHASAN}

\section{Tinjauan dan Fungsi Manajemen}

\section{Pengertian Manajemen}

Untuk mencapai tujuan yang telah ditentukan, organisasi termasuk madrasah harus digerakkan dengan suatu kegiatan yang dikenal dengan manajemen. Manajemen merupakan suatu proses kegiatan untuk mencapai suatu tujuan. Manajemen dilaksanakan dengan mengatur dan mengarahkan berbagai sumber daya yang dirumuskan menjadi enam M, yaitu man (manusia), money (uang), material (barang), machine (mesin), method (metode), dan market (pasar). Keseluruhan sumber daya itu disebut unsur manajemen yang harus dikoordinasikan oleh pimpinan lembaga tertentu secara berimbang untuk mencapat tujuan. ${ }^{6}$

Manajemen dapat didefinisikan dengan berbagai rumusan. Manajemen ${ }^{7}$ adalah seni dan kemampuan memperoleh hasil, melalui kegiatan orang lain untuk mencapai tujuan yang ditetapkan sebelumnya. ${ }^{8}$ Sedangkan menurut Soemitro Djoyokusuma, manajemen adalah usaha mengatur dan memimpin. ${ }^{9}$ Dari pengertian di atas dapat dikemukakan bahwa orientasi manajemen adalah memperoleh hasil dengan melalui kegiatan operasional. Berkaitan dengan itu, Robert Kreitener mendefinisikan manajemen sebagai berikut:

Management is the process of working with and through others to achieve organizational objectives in a changing environment. Central to this process is the effective and efficient use of limited resources. ${ }^{10}$

Definisi tersebut bermakna bahwa manajemen adalah proses bekerja dengan dan melalui orang lain untuk mencapai tujuan organisasi dalam lingkungan yang 
berubah. Proses ini berpusat pada penggunaan secara efektif dan efisien sumber daya yang terbatas.

Dengan menggunakan kata kunci working with and through others, memberi kesan bahwa manajer bukan hanya dapat menyuruh orang lain, tetapi ia sendiri juga mampu melakukannya dan memberi contoh. Kata kunci lain yang perlu diperhatikan adalah in a changing environment, yang menekankan agar selalu memerhatikan lingkungan yang berubah terus-menerus, sehingga diperlukan langkah yang dinamis dan strategis. Sedangkan limited resources mengingatkan bahwa betapa pun banyaknya sumber daya itu terbatas.

Dari uraian tersebut dapat dipahami bahwa manajemen adalah aktivitas untuk mengatur kegunaan sumber daya bagi tercapainya tujuan organisasi secara efektif. Pimpinan yang mengatur aktivitas disebut manager (manajer) dan anggota yang terlibat dalam pelaksanaan manajemen disebut management staff (staf manajemen). Pencapaian tujuan organisasi ditempuh melalui pemanfaatan sumber daya dan sarana serta kerjasaman sejumlah orang sebagai pelaksana.

\section{Fungsi-fungsi Manajemen}

Aktivitas manajemen mencakup spektrum yang sangat luas, sebab dimulai dari menentukan arah organisasi pada masa depan, menciptakan kegiatan organisasi, mendorong terbinanya kerjasama antara sesama anggota organisasi, serta mengawasi kegiatan dalam mencapai tujuan.

Manajemen memiliki peranan yang sangat strategis dalam mengefektifkan usaha organisasi, terutama untuk membantu pencapaian yang lebih baik dalam mendayagunakan peralatan, lahan, kantor, produk, pelayanan, dan hubungan manusia dalam organisasi. ${ }^{11}$

Dalam rangka mencapai tujuan organisasi secara efektif dan efisien itulah manajemen harus difungsikan sepenuhnya pada setiap organisasi, baik organisasi industri, perbankan maupun organisasi pendidikan. Fungsi manajemen tersebut terdiri atas:

\section{Perencanaan (Planning)}

Perencanaan merupakan tindakan awal dalam aktivitas manajerial pada setiap organisasi. Karena itu, perencanaan akan menentukan adanya perbedaan kinerja satu organisasi dengan organisasi lain dalam pelaksanaan rencana untuk mencapai tujuan. ${ }^{12}$ Perencanaan ditentukan tujuan yang dicapai dengan membuat rencana dan caracara melakukan rencana untuk mencapai tujuan yang ditetapkan para manajemen pada setiap level manajemen.

2. Pengorganisasian (Organizing)

Pengorganisasian merupakan fungsi manajemen yang kedua dan merupakan langkah strategis untuk mewujudkan suatu rencana organisasi. Pengorganisasian adalah suatu proses yang dibagi dalam komponen-komponen yang dapat ditangani dan aktivitas-aktivitas yang mengoordinasikan hasil yang dicapai untuk mencapai tujuan tertentu. ${ }^{13}$ Pengorganisasian berfungsi untuk membagi kerja terhadap berbagai bidang, menetapkan kewenangan dan pengordinasian kegiatan bidang yang berbeda untuk menjamin tujuan dan mengurangi konflik yang terjadi dalam organisasi. 


\section{Pengaturan (Directing)}

Pada hakikatnya pengarahan mengandung kegiatan pemberian motivasi (motivating). Kegiatan ini terdapat pada kegiatan directing sebagai suatu fasilitas atau sarana melakukan pengarahan terhadap para personil dalam organisasi. Motivasi berkaitan erat dengan kebutuhan.

Memotivasi atau pemberian motivasi dalam konteks organisasi adalah proses seorang manajer merangsang pihak lain untuk bekerja dalam rangka mencapai sasaran organisasi sebagai alat untuk memuaskan keinginan pribadi mereka sendiri. ${ }^{14}$

\section{Koordinasi (Coordinating)}

Koordinasi adalah salah satu fungsi manajemen yang mengimplikasikan bahwa elemen-elemen suatu organisasi saling berhubungan dan menunjukkan keterkaitan sedemikian rupa sehingga semua orang melaksanakan tindakan tepat waktu dalam rangka mencapai tujuan. ${ }^{15}$

Jadi, koordinasi merupakan proses yang melibatkan pemindahan informasi antara pekerjaan dan orang untuk menghindarkan pekerjaan yang tumpang tindih, menjamin usaha dan sumber penghasilan serta keseimbangan keseluruhan organisasi.

5. Kepemimpinan (Leadership)

Kepemimpinan sebagai suatu proses di dalamnya mengandung interaksi tiga faktor, yaitu fungsi pemimpin, pengikut (anggota), dan situasi yang memengaruhinya. ${ }^{16}$ Kepemimpinan terdiri atas seperangkat fungsi atau tindakan yang dilakukan oleh individu untuk menjamin terlaksananya tugas, iklim kerjasama kelompok, kepuasan anggota yang berhubungan dengan tujuan organisasi.

\section{Komunikasi (Communicating)}

Dalam berbagai organisasi termasuk madrasah diperlukan komunikasi di antara para anggotanya. Sifat dasar komunikasi sebenarnya bertumpu pada pertukaran pesan di antara anggota organisasi tertentu untuk mencapai tujuan yang ingin dicapai.

7. Pengawasan (Controlling)

Sebagai salah satu fungsi manajemen, pengawasan merupakan tindakan terakhir yang dilakukan para manajer dalam suatu organisasi. Pengawasan merupakan pengamatan atau pemantauan terhadap pelaksanaan kegiatan organisasi untuk menjamin agar semua pekerjaan yang sedang dilakukan berjalan sesuai dengan rencana yang telah ditentukan sebelumnya. ${ }^{17}$

Pengawasan yang dilakukan merupkan strategi untuk menghindari penyimpangan dari segi pendekatan rasional terhadap keberadaan input dan pengawasan terhadap aktivitas.

\section{Kepemimpinan Pendidikan di Madrasah}

Kemimpinan dalam suatu organisasi sangat dibutuhkan untuk berlangsunnya kegiatan organisasi secara efektif. Fungsi kepemimpinan pendidikan adalah pencapaian visi dan misi lembaga pendidikan termasuk madrasah yang dilihat dari mutu pembelajaran yang dicapai. 
Para pimpinan lembaga pendidikan memerlukan kemampuan berpikir kreatif dalam menjalankan kepemimpinannya dan salah satu peranan utamanya ialah pengambilan keputusan pendidikan secara efektif. ${ }^{18}$ Cara kerja kepala madrasah dan cara memandang peranannya dipengaruhi oleh kepribadiannya, persiapan, dan pengalaman profesionalnya serta ketetapan yang dibuat oleh madrasah mengenai peranan kepala madrasah di bidang pendidikan.

Kepemimpinan pendidikan bertugas meningkatkan kinerja yang tinggi menjalankan kebijakan pemerintah. Karena itu, karakteristik kepemimpinan pendidikan yang efektif yaitu memberi pengarahan, menciptakan inspirasi, membangun tim kerja, menjadi teladan (uswah hasanah), dan menciptakan penerimaan di kalangan personil. ${ }^{19}$

Kepemimpinan pendidikan ialah kemampuan untuk memengaruhi dan menggerakkan orang lain untuk mencapai tujuan pendidikan secara terarah. ${ }^{20}$ Kepemimpinan pendidikan juga diartikan sebagai:

Suatu kemampuan dan proses memengaruhi, mengoordinir dan menggerakkan orangorang lain yang ada hubungan dengan pengembangan ilmu pendidikan dan pelaksanaan pendidikan serta pembelajaran agar supaya kegiatan-kegiatan yang dijalankan dapat lebih efisien dan efektif di dalam pencapaian tujuan-tujuan pendidikan dan pengajaran. ${ }^{21}$

Kepemimpinan pendidikan di madrasah harus dilandasi konsep demokratisasi, spesialisasi tugas, pendelegasian wewenang, profesionalitas, dan integrasi tugas untuk mencapai tujuan bersama. Kepemimpinan yang berlangsung pada lembaga pendidikan berarti menjalankan proses kepemimpinan yang sifatnya memengaruhi sumber daya personil pendidikan (pendidik dan tenaga kependidikan) agar melakukan tindakan bersama guna mencapai tujuan pendidikan. Kepemimpinan pendidikan di madrasah itu dijalankan oleh seorang kepala madrasah.

Sebagai seorang pemimpin, tugas-tugas kepala madrasah sebagai seorang pemimpin lembaga pendidikan masa depan tidak cukup hanya sekadar melakukan peran-peran yang berkenaan dengan perencanaan, mengomunikasikan, mengoordinasikan, memotivasi, mengendalikan, mengarahkan dan memimpin. Lebih dari itu, wilayah tugas pemimpin masa depan, termasuk pemimpin madrasah, harus disempurnakan dengan kegiatan-kegiatan yang membuat orang yang dipimpin mampu, memperlancar, tempat berkonsultasi, membangun kerjasama, membimbing, membagi cinta kasih, mensejahterakan dan mendukung. Dengan demikian, terlihat bahwa hubungan pemimpin dan yang dipimpin, tidak sebagaimana hubungan buruh dan majikannya, patron dan kliennya, melainkan terjalin hubungan kolegial di antara orang-orang yang masing-masing memiliki tanggung jawab atau integritas pengabdian yang tinggi.

Penulis dapat menyimpulkan bahwa kepemimpinan pendidikan adalah kepemimpinan kepada madrasah itu sendiri. Kepemimpinan tersebut harus dijalankan sebagai suatu proses memengaruhi personil yang terlibat dalam pengelolaan madrasah dan kegiatan pembelajaran dalam rangka pencapaian tujuan pendidikan secara efektif dan efisien. Di sinilah peranan kepala madrasah bertindak sebagai manajer 
atau pimpinan lembaga pendidikan untuk melakukan perubahan sebuah organisasi formal pendidikan.

\section{Konsep Manajemen dan Kepemimpinan Madrasah}

Menghadapi masa depan yang masih penuh tantangan dan persaingan maka setiap organisasi pendidikan khususnya pendidikan madrasah, perlu mempersiapkan diri dengan menata organisasi, administrasi dan manajemen sebagai salah satu perangkat untuk memperkuat daya saing ke depan.

Pengelola madrasah, jika dilihat dari sisi etos kerja, memiliki semangat atau motivasi yang tinggi. Dalam hal membangun madrasah, bagi masyarakat tertentu, mereka tidak pernah membayangkan akan memperoleh keuntungan yang bersifat materi. Bahkan mereka mampu menunjukkan kesadaran betapa pentingnya lembaga pendidikan Islam ini melalui pengorbanan berupa apa saja yang mereka miliki. Tidak jarang ditemui, orang yang bersedia menjual tanah atau hewan ternak untuk membiayai pembangunan madrasah. Jiwa berkorban seperti ini agaknya sulit ditemui di lingkungan masyarakat yang menamakan diri telah memasuki dunia modern. Jiwa berkorban yang tinggi juga tidak jarang ditunjukkan oleh pendidik. Selain mereka bersedia menjalankan tugas-tugas kependidikan semampunya, mereka sanggup menambah pengetahuan dengan biaya sendiri dengan cara patungan. Hal itu berbeda dengan mereka yang berjiwa pegawai, baru mau menambah dan atau mengimplementasikan konsep baru jika telah tersedia dana proyek yang dibutuhkan. Nyata sekali bahwa pada satu sisi, madrasah sekalipun kondisinya memprihatinkan tetapi menyandang jiwa pejuang namun di tengah-tengah banyak pihak berkekurangan itu justru tumbuh sebagian orang yang pada diri mereka tumbuh jiwa pegawai. Oleh karena itu nyata sekali bahwa dalam manajemen pendidikan di tanah air ini terjadi diskriminasi, ketidakadilan dan kurang mencerminkan kebhinekaan yang seharusnya dijunjung tinggi. Hal itu mengakibatkan sebagian lembaga pendidikan yang kebanyakan berstatus swasta, dalam hal ini madrasah, mengalami keterpurukan.

Madrasah sebagai salah satu bagian sistem pendidikan nasional tentu memerlukan perhatian dan pengelolaan secara serius. Karena itu, manajemen dan kepemimpinan madrasah ke depan dengan perubahan masyarakat yang semakin cepat dan terbuka menuntut kemampuan yang lebih kreatif, inovatif dan dinamis. Kepala madrasah yang sekadar bergaya menunggu dan terlalu berpegang pada aturan-aturan birokratis dan berpikir secara struktural dan tidak berani melakukan inovasi untuk menyesuaikan tuntutan masyarakatnya, akan ditinggalkan oleh peminatnya. Pada masyarakat yang semakin berkembang demikian cepat dan di dalamnya terjadi kompetisi secara terbuka selalu dituntut kualitas pelayanan yang berbeda dengan masyarakat sebelumnya. Perlu disadari bahwa ciri khas masyarakat maju adalah pemegang kendali bukan lagi produsen melainkan konsumen, pilihan-pilihan sudah semakin banyak dan beragam, mereka menuntut kualitas dan pelayanan prima. Tuntutan semacam ini hanya dapat dipenuhi oleh kepala madrasah yang berdaya (empowered), kreatif, memiliki kemampuan leadership dan manajerial yang tangguh, tidak mengenal lelah dan tak kenal putus asa. Apalagi madrasah sudah terintegrasi ke dalam 
Undang-Undang Republik Indonesia nomor 20 tahun 2003 tentang Sistem Pendidikan Nasional sebagai suatu pengakuan bahwa madrasah adalah bagian dari sistem pendidikan nasional walaupun pengelolaannya masih dilakukan oleh Kementerian Agama. ${ }^{22}$

Manajemen kepemimpinan di madrasah selama ini pada umumnya bercorak alami. Baik pengembangan madrasah maupun proses pembinaan calon pimpinan yang akan menggantikan pimpinan yang ada, belum memiliki bentuk yang teratur dan menetap. ${ }^{23}$ Banyak hal yang dapat ditunjuk sebagai sebab belum menetapnya pola kepemimpinan di madrasah selama ini. Sebab yang paling utama adalah watak kharismatik yang dimilikinya. Pada tahap-tahap pertama berkembangnya suatu madrasah memang diperlukan kepemimpinan dengan sifat-sifat sedemikian itu, tetapi pada tahap selanjutnya banyak kerugian yang ditimbulkan. Pertama, munculnya ketidakpastian dalam perkembangan madrasah yang bersangkutan, karena semua hal bergantung pada keputusan pribadi sang pemimpin. Kedua, pola pergantian pimpinan berlangsung secara tiba-tiba dan tidak direncanakan, sehingga lebih banyak ditandai oleh sebab-sebab alami seperti meninggalnya sang pemimpin secara mendadak. Ketiga, terjadinya pembaharuan dalam tingkat-tingkat kepemimpinan di madrasah, antara tingkat lokal, regional, dan nasional. ${ }^{24}$

Sebelum sampai kepada persoalan kepemimpinan dalam pengembangan madrasah, terlebih dahulu akan dikemukakan beberapa hal sebagai latar belakang kebutuhan terhadap pengembangan itu sendiri, dan perlunya perumusan tentang integrasi madrasah ke dalam pendidikan nasional beserta proyek-proyek rintisannya.

Kenyataan seperti ini menunjukkan bahwa hingga saat ini masalah porsi agama semakin lama semakin menurun dengan membawa akibat mentahnya lulusan yang dihasilkan oleh madrasah, tidak menjadi agamawan yang berpengetahuan agama yang mendalam, dan juga tidak menjadi ilmuan nonagama yang cukup tinggi kualitasnya. Yang terjadi adalah pembaharuan (akulturasi) yang tidak memperlihatkan identitas yang jelas. Mungkin menghadapi kenyataan seperti itu, sebagian pemimpin madrasah cenderung untuk kembali pada "cara salaf", di mana porsi pelayanan pada komponen nonagama dalam kurikulumnya hampir tidak ada.

Tujuan pengembangan madrasah adalah integrasi antara pengetahuan agama dan nonagama sehingga lulusan yang dihasilkan akan memiliki kepribadian yang utuh dan bulat, yang menggabungkan dalam dirinya unsur-unsur keimanan yang kuat dan penguasaan atas pengetahuan secara berimbang. ${ }^{25}$ Manusia seperti itu memiliki cakrawala pemikiran yang luas, pandangan hidup yang matang, dan pendekatan yang praktis dan berwatak multi sektoral dalam memecahkan persoalan yang dihadapi.

Program pengembangan madrasah yang sedang dijalankan, baik oleh kalangan madrasah sendiri secara internal maupun oleh kalangan eksternal yang bekerja sama dengan madrasah tertentu. Madrasah harus mampu menerapkan dan menjalankan konsep manajemen berbasis masyarakat atau juga manajemen berbasis sekolah atau kalau di lingkungan madrasah disebut manajemen berbasis madrasah (society based- 
management). ${ }^{26}$ Jika manajemen berbasis masyarakat itu diartikan sebagai pengelolaan lembaga pendidikan dikembalikan pada masyarakat, maka sesungguhnya madrasah merupakan potret lembaga pendidikan yang menerapkan konsep itu.

Pada kenyataannya, belajar dari kasus kehidupan madrasah, terdapat korelasi yang amat signifikan antara tingkat ekonomi masyarakat dengan kemajuan lembaga pendidikannya. Bagi masyarakat yang sudah berekonomi cukup maju dan peduli pada madrasah, maka lembaga pendidikan Islam akan berkembang. Artinya, lembaga pendidikan itu akan mampu mengembangkan diri dalam arti mampu menyediakan tenaga guru yang memenuhi syarat, sarana dan prasarana pendidikan, kurikulum, membangun manajemen yang kokoh dan lainnya. Akan tetapi, jika masyarakatnya lemah, sekalipun mereka memiliki kepedulian terhadap pendidikan yang tinggi tetapi tidak akan mampu menyangga kebutuhan lembaga pendidikan secara memadai. Jika konsep manajemen berbasis masyarakat diterapkan untuk pengembangan pendidikan dalam pengertian sepenuhnya, maka hasilnya akan seperti yang dialami madrasah selama ini. Pengelolaan pendidikan di negara berkembang seperti Indonesia ini rupanya justru mengharuskan pemerintah menanggung seluruh biaya pendidikan tingkat dasar dan menengah, tanpa memandang status negeri atau swasta, secara cukup. Pembedaan perlakuan hanya dimungkinkan pada tingkat pendidikan tinggi. Alasannya, bahwa seluruh warga negara, secara adil tanpa diskriminatif seharusnya mengenyam pendidikan pada tingkat dasar. Jika sekelompok masyarakat tidak mengenyam pendidikan dasar maka akan menjadi kekuatan penghambat terhadap kemajuan secara keseluruhan yang diinginkan bersama.

Selama ini disadari atau tidak, telah tumbuh perlakuan kurang adil dalam melakukan penilaian terhadap lembaga pendidikan madrasah. Madrasah yang berjumlah tidak kurang dari $15 \%$ dari total lembaga pendidikan yang ada, dan menurut catatan tidak kurang dari $90 \%$ berstatus swasta selalu dibandingkan dengan sekolah umum dalam mencapaian prestasinya. ${ }^{27}$

Membandingkan dua hal yang tidak sebanding adalah merupakan langkah yang kurang adil. Sekolah umum yang pada umumnya berstatus negeri dan dengan statusnya itu seluruh pembiayaan, ketenagaan, semua kebutuhan fasilitas tercukupi oleh pemerintah dibandingkan dengan prestasi madrasah yang pada umumnya berstatus swasta dan tidak memperoleh fasilitas sebagaimana yang diterima oleh sekolah umum pada umumnya. Tambahan lagi, bahwa madrasah dan sekolah umum memiliki kharakteristik dan orientasi yang membawa konsekuensi beban berbeda. Madrasah untuk membangun ciri khasnya, mereka menambah beban dengan cara memberi penguatan pada aspek keagamaan (Islam) yang sesungguhnya merupakan kekuatan tersendiri, akan tetapi tidak pernah memperoleh perhargaan lebih tatkala membandingkan di antara keduanya. Ketika pada umum orang gelisah dengan fenomena maraknya perkelahian antar-siswa, merebaknya kasus-kasus penggunaan obat terlarang di kalangan siswa, pergaulan bebas dan seterusnya, fenomena madrasah jauh dari citra buruk seperti itu. Pengamatan selama ini sedikit sekali ditemukan kasuskasus negatif seperti itu di madrasah, lantaran kekuatan spiritual yang dikembang- 
kan. Kenyataan ini belum pernah memperoleh pengakuan semestinya. Perbandingan antara madrasah dan sekolah umum selama ini hanya sebatas hasil akhir ujian nasional atau UN dan menghasilkan kesimpulan bahwa prestasi UN pada masingmasing jenjang madrasah lebih rendah dari sekolah umum. Sedangkan prestasi membangun akhlak atau budi pekerti dari kedua jenis lembaga pendidikan tersebut tidak pernah dilihat, sehingga seolah-olah aspek itu dipandang kurang penting. Padahal, yang sesungguhnya tatkala bangsa tidak memiliki karakter, akhlak atau kepribadian maka segala-galanya akan tidak bermakna, sekalipun mereka menyandang intelektualitas yang tinggi. Kata kunci dalam mengelola pendidikan semestinya harus mengedepankan kebersamaan, kesemestaan, keadilan, dan dijauhkan perlakuan diskriminasi, maka madrasah akan mampu bersaing dan akan survival dengan konsep dan kekuatan yang disandang.

Manajemen madrasah, dukungan kelas berfungsi mensinkronkan berbagai input tersebut atau mensinergikan semua komponen dalam interaksi (proses) belajar mengajar baik antara guru, siswa dan sarana pendukung di kelas maupun di luar kelas; baik konteks kurikuler maupun ekstra-kurikuler, baik dalam lingkup subtansi yang akademis maupun yang non-akademis dalam suasana yang mendukung proses pembelajaran.

Kualitas dalam konteks hasil pendidikan mengacu pada prestasi yang dicapai oleh sekolah pada setiap kurun waktu tertentu. Prestasi yang dicapai (student achievement) dapat berupa hasil tes kemampuan akademis atau prestasi di bidang lain. Sedangkan pendidikan adalah usaha sadar dan terencana untuk mewujudkan suasana belajar dan proses pembelajaran agar peserta didik secara aktif mengembangkan potensi dirinya untuk memiliki kekuatan spiritual keagamaan, pengendalian diri, kepribadian, kecerdasan, akhlak mulia, serta keterampilan yang diperlukan dirinya dan masyarakat. ${ }^{28}$

Pendidikan meliputi pengajaran keahlian khusus, dan juga sesuatu yang tidak dapat dilihat tetapi lebih mendalam yaitu pemberian pengetahuan, pertimbangan dan kebijaksanaan. Salah satu dasar utama pendidikan adalah untuk mengajar kebudayaan melewati generasi.

Adapun pengembangan kepemimpinan madrasah merupakan tuntutan untuk memahami dan bersedia mengikuti program-program pengembangan di atas, pimpinan madrasah yang memiliki kepemimpinan yang relevan dengan kebutuhan sekarang dan masa depan harus pula mampu memahami kebutuhan integrasi madrasah ke dalam pendidikan nasional. Bagaimanapun juga harus diakui bahwa saat ini madrasah sebagai suatu sistem pendidikan masih berada diluar area pendidikan nasional yang ada. Secara potensial ia merupakan salah satu dari lembaga pendidikan yang ideal bagi bangsa kita karena kemampuannya mengembangkan watak mandiri dalam diri para lulusannya selama ini. ${ }^{29}$ Kepemimpinan yang dinamis di madrasah harus mampu mengadakan proyek-proyek rintisan yang akan menonjolkan sumbangan positif madrasah bagi pendidikan nasional, baik dalam program pendidikannya, sistem pendidikannya, maupun metode pengajarannya. Pada taraf regional, kepemim- 
pinan madrasah yang dinamis haruslah mampu menciptakan dukungan dan topangan bagi proyek-proyek rintisan itu, lebih-lebih lagi dalam bentuk pengayoman semua pihak yang berkepentingan terhadap perkembangan pendidikan. Pada taraf nasional, kepemimpinan madrasah yang dinamis akan mampu menyuguhkan kerangkakerangka teoritis dan filosofis bagi pembentukan pendidikan nasional yang relevan dengan kebutuhan bangsa kita di masa depan. ${ }^{30}$

Kepemimpinan dalam bentuk penerangan madrasah yang dinamis dan memiliki pandangan yang jauh ke masa depan. ${ }^{31}$ Kepemimpinan madrasah hendaknya jangan hanya sibuk dengan fungsi kemasyarakatan yang sempit (pelayanan individual kepada wali murid) belaka, dan juga hanya disempitkan oleh pelayanan teknis pada madrasah sendiri saja (seperti pengawasan administratif dan pembinaan calon pengganti secara teratur). Kepemimpinan yang sempit seperti itu dalam jangka panjang hanya akan tercecer oleh perkembangan di luar madrasah. Yang diperlukan adalah pendayagunaan kepemimpinan yang sudah memiliki keterampilan praktis yang sempit di bidang pengawasan, administrasi, dan perencanaan itu guna tujuan yang lebih besar: bagaimana mengintegrasikan madrasah ke dalam pendidikan nasional.

Bahwa lembaga pendidikan adalah cenderung pada suatu model manajemen organisasi, mengelola suatu pendidikan tidak bisa tanpa melibatkan pada orang lain dan tidak bisa lembaga pendidikan ditangani sendiri. Oleh karena itu untuk mewujudkan suatu tujuan akhir (final goal) harus melibatkan orang lain. ${ }^{32}$ Kekuatan manajemen dapat dilihat secara eksternal lewat pertumbuhan atau kemajuan suatu lembaga, karena banyak sekali sekolah yang ditangani oleh seorang yang pandai melibatkan orang lain menjadi sekolah yang maju dan favorit. Tentu orang tersebut mempunyai kekuatan atau kepandaian dalam manajemen personalia. Sekolah yang maju dan tumbuh dengan cepat dapat dipastikan bahwa lembaga itu memiliki kekuatan manajemen.

Reformasi diri yang perlu dilakukan sekolah adalah perbaikan proses pendidikan dimulai dari perubahan psikologis, budaya, dan sosial para pengelolanya. Kepala sekolah harus mereformasi diri menjadi kepala sekolah yang kolaboratif, sehingga menumbuhkan iklim sekolah yang demokratis. Pembenahan kepemimpinan sekolah merupakan unsur utama dalam manajemen peningkatan kualitas pendidikan sehingga sekolah dapat mandiri, kreatif dan inovatif dalam melaksanakan kegiatan pendidikan sesuai dengan sumber daya pendidikan yang tersedia. ${ }^{33}$

Memerhatikan tantangan dan tanggung jawab kepala madrasah ke depan, di tambah lagi dengan tuntutan yang semakin komplek untuk menyesuaikan dengan tuntutan zamannya, maka ada beberapa hal yang perlu dikembangkan untuk meningkatkan kinerja kepala madrasah, antara lain: (1) memberikan space yang luas agar dimungkinkan mereka melakukan kreativitas dan eksperimen pengembangan madrasah dalam berbagai aspeknya, misalnya pengembangan ketenagaan, kurikulum, manajemen dan kepemimpinannya pada madrasah yang dipimpinnya sehingga tersedia ruang berkreativitas secara memadai, (2) memberikan kepercayaan yang lebih luas sehingga ada sikap saling percaya (mutual trust), (3) memperkaya sumber-sum- 
ber informasi yang mencukupi, sehingga suasana lembaga tidak kering (resourceful), (4) membantu menghilangkan rintangan atau halangan sehingga tidak banyak kendala (constraints), (5) memfasilitasi sehingga lembaga fasilitatif dan (6) mengevaluasi secara menyeluruh, jujur dan adil, baik pada tataran proses maupun produknya, sehingga ada akuntabilitas (accountability). ${ }^{34}$

Dengan demikian manajemen pendidikan merupakan alternatif strategis untuk meningkatkan kualitas pendidikan.

\section{PENUTUP}

Dari uraian pembahasan makalah tersebut, penulis mengambil kesimpulan sebagai berikut:

1. Aktivitas manajemen mencakup spektrum yang sangat luas, sebab dimulai dari menentukan arah organisasi di masa depan, menciptakan kegiatan organisasi, mendorong terbinanya kerjasama antara sesama anggota organisasi, serta mengawasi kegiatan dalam mencapai tujuan dan manajemen memiliki peranan yang sangat strategis dalam mengefektifkan usaha organisasi, terutama untuk membantu pencapaian yang lebih baik dalam mendayagunakan peralatan, lahan, kantor, produk, pelayanan, dan hubungan manusia dalam organisasi.

2. Kepemimpinan pendidikan di madrasah harus dilandasi konsep demokratisasi, spesialisasi tugas, pendelegasian wewenang, profesionalitas, dan integrasi tugas untuk mencapai tujuan bersama. Kepemimpinan yang berlangsung pada lembaga pendidikan berarti menjalankan proses kepemimpinan yang sifatnya mempengaruhi sumber daya personil pendidikan (pendidik dan tenaga kependidikan) agar melakukan tindakan bersama guna mencapai tujuan pendidikan. Kepemimpinan pendidikan di madrasah itu dijalankan oleh seorang kepala madrasah.

3. Manajemen madrasah dan pelaksanaan kepemimpinan di madrasah harus mampu mensinkronkan berbagai input tersebut atau mensinergikan semua komponen dalam interaksi (proses) pembelajar baik antara guru, siswa dan sarana pendukung di kelas maupun di luar kelas; baik konteks kurikuler maupun ekstrakurikuler, baik dalam lingkup substansi yang akademis maupun yang non-akademis dalam suasana yang mendukung proses pembelajaran sehingga madrasah mampu eksis di tengah tuntutan zaman.

\section{CATATAN AKHIR:}

1. Abuddin Nata, Manajemen Pendidikan: Mengatasi Kelemahan Pendidikan Islam di Indonesia, cet. I: Jakarta: Kencana, 2003, h. 7.

2. Mappanganro, Eksistensi Madrasah dalam Sistem Pendidikan Nasional, cet. I; Ujung Pandang:Berkah Utami, 1996, h. 11.

3. M. Arifin, Kapita Selekta Pendidikan Islam, cet. I; Jakarta:Bumi Aksara, 2003, h. 47.

4. Anwar Arifin, Mutu Pendidikan Indonesia Masih Terpuruk, "www.gatra.com", akses 10 Oktober 2011.

5. Kementerian Agama RI., Statistik Madrasah, www.kemenag.go.id., akses 10 Oktober 2011.

6. Zaimi Mochtarom, Dasar-dasar Manajemen Dakwah, Yogyakarta: al-Amin Press, 2000, h. 35. 
7. Dalam manajemen di samping dikenal adanya fungsi manajemen antara lain perencanaan, pengorganisasian, pelaksanaan dan pengawasan. Untuk mencapai tujuan suatu organisasi maka unsur manajemen perlu dioprasionalkan dengan memamfaatkan fungsi manajemen, sebelumnya organisasi dapat mencapai tujuannya. Seorang manajer juga harus berani melaksanakan perubahan dan pembaharuan tanpa mengabaikan kode etik dengan cara, yaitu: pertama, kesediaan dengan ikhlas untuk berubah sesuai perubahan lingkungan global. Kedua memantapkan visi, misi dan strateginya secara jelas dalam mencapai tujuan yang dicita-citakan. Ketiga, menyusun rencana oprasional secara konkrit baik jangka pendek maupun jangka panjang, dan keempat program pelaksanaan, pemantauan serta penilaian hasil pencapaian tujuan harus dilaksanakan secara transparan. A. Kube Dauda "Pembinaan Organisasi, Administrasi, dan Manajemen Madrasah/Pesantren" Makalah Musyawarah Kerja PB. As'adiyah, Sengkang: Gedung Yusbar, 2002 h.., h. 10.

8. Ibid., h. 3.

9. Nanang Fattah, Landasan Manajemen Pendidikan, cet. III; Bandung: PT. Remaja Rosda Karya, 2000, h. 15.

10. Robert Kreitener, Management, Boston: Houghton Miffilin Company, 2001, h. 9.

11. Syafaruddin, Manajemen Lembaga Pendidikan Islam, cet. I; Jakarta: Ciputat Press, 2005, h. 60.

12. Ibid., h. 61.

13. Winardi, Asas-asas Manajemen, cet. I; Bandung: Mandar Maju, 2002, h. 21.

14. Ibid., h. 23.

15. Syafaruddin, op. cit., h. 79.

16. Ibid., h. 84.

17. Sondang Siagian, Manajemen Strategik, Jakarta: Gunung Agung, 1999, h. 46.

18. Hendiyat Soetopo, et al., Administrasi Pendidikan, Surabaya: Usaha Nasional, 2000, h. 39.

19. Syafaruddin, op. cit., h. 158.

20. Hendiyat Soetopo, op. cit., h. 42.

21. Dirawat, et al., Kepemimpinan Pendidikan, Surabaya: Usaha Nasional, 2000, h. 33.

22. Maksum, Madrasah Sejarah dan Perkembangannya, cet. II; Jakarta: Logos Wacana Ilmu, 1999, h. 34 .

23. Mappanganro, op. cit., h. 11.

24. Abdurrahman Wahid, Menggerakkan Tradisi Esai-Esai Pesantren, cet. I; Yogyakarta: LkiS, 2001, h. 135.

25. Ibid., h. 137.

26. Ahmad Rozikun, et al., Strategi Perencanaan Manajemen Berbasis Madrasah (MBM) di Tingkat Menengah, cet. II; Jakarta: Liska Fariska Putra, 2008, h. 10-15.

27. Admin, Mencermati Aspek Manajemen Madrasah, www.uinmalang.ac.id/, akses 10 Oktober 2011.

28. Tim Wikipedia Indonesia, Pendidikan, "http://id.wikipedia.org," akses 10 Oktober 2011.

29. Ibid., h. 141.

30. Ali Ashraf, Horison Baru Pendidikan Islam, cet. III; t.tp: Pustaka Pirdaus, 1996, h. 5.

31. Abdurrahman Wahid, op. cit., h. 143.

32. Sudarwan Danim, Visi Baru Manajemen Sekolah, cet. III; Jakarta: Bumi Aksara, 2008, h. 101.

33. Indra Djati Sidi, Menuju Masyarakat Belajar: Menggagas Paradigma Baru Pendidikan, cet. I; Jakarta: Paramadina, 2003, h. 76.

34. H. Imam Suprayogo, Memimpin Madrasah Agar Lebih Dinamis,_rektor.uinmalang.ac.id, akses 10 Oktober 2011 


\section{DAFTAR PUSTAKA:}

Arifin, Anwar, Mutu Pendidikan Indonesia Masih Terpuruk, "www.gatra.com”, akses 10 Oktober 2011.

Arifin, Muzayyin, Kapita Selekta Pendidikan Islam, cet. I; Jakarta:Bumi Aksara, 2003.

Danim, Sudarwan, Visi Baru Manajemen Sekolah, cet. III; Jakarta: Bumi Aksara, 2008.

Dauda, A. Kube, "Pembinaan Organisasi, Administrasi, dan Manajemen Madrasah/Pesantren" Makalah Musyawarah Kerja PB. As'adiyah, Sengkang: Gedung Yusbar, 2002.

Dirawat, et al., Kepemimpinan Pendidikan, Surabaya: Usaha Nasional, 2000.

Fattah, Nanang, Landasan Manajemen Pendidikan, cet. III; Bandung: PT. Remaja Rosda Karya, 2000.

Kementerian Agama RI., Statistik Madrasah, www.kemenag.go.id., akses 10 Oktober 2011.

Kreitener, Robert, Management, Boston: Houghton Miffilin Company, 2001.

Maksum, Madrasah Sejarah dan Perkembangannya, cet. II; Jakarta: Logos Wacana Ilmu, 1999.

Mappanganro, Eksistensi Madrasah dalam Sistem Pendidikan Nasional, cet. I; Ujung Pandang: Berkah Utami, 1996.

Mochtarom, Zaimi, Dasar-dasar Manajemen Dakwah, Yogyakarta: al-Amin Press, 2000.

Nata, Abuddin, Manajemen Pendidikan: Mengatasi Kelemahan Pendidikan Islam di Indonesia, cet. I: Jakarta: Kencana, 2003.

Rozikun, Ahmad, et al., Strategi Perencanaan Manajemen Berbasis Madrasah (MBM) di Tingkat Menengah, cet. II; Jakarta: Liska Fariska Putra, 2008.

Siagian, Manajemen Strategik, Jakarta: Gunung Agung, 1999.

Sidi, Indra Djati, Menuju Masyarakat Belajar: Menggagas Paradigma Baru Pendidikan, cet. I; Jakarta: Paramadina, 2003.

Soetopo, Hendiyat. et al., Administrasi Pendidikan, Surabaya: Usaha Nasional, 2000.

Suprayogo, Imam, Memimpin Madrasah Agar Lebih Dinamis, rektor.uinmalang.ac.id, akses 10 Oktober 2011

Syafaruddin, Manajemen Lembaga Pendidikan Islam, cet. I; Jakarta: Ciputat Press, 2005.

Wahid, Abdurrahman, Menggerakkan Tradisi Esai-Esai Pesantren, cet. I; Yogyakarta: LkiS, 2001.

Winardi, Asas-asas Manajemen, cet. I; Bandung: Mandar Maju, 2002. 